\title{
Estudo cinético de células de Drosophila melanogaster transfectadas para a produção da glicoproteína da raiva em biorreator.
}

Dissertação apresentada ao Programa de Pós-Graduação Interunidades em Biotecnologia USP/ Instituto Butantan / IPT, para obtenção do Título de Mestre em Biotecnologia

Área de concentração:

Biotecnologia

Orientadora: Elisabeth de Fátima Pires Augusto 


\section{RESUMO}

AGUIAR, M. A. Estudo cinético de células de Drosophila melanogaster transfectadas para a produção da glicoproteína do vírus da raiva em biorreator. 2010. 124 f. [Dissertação]. São Paulo - Instituto de Ciências Biomédicas da Universidade de São Paulo, São Paulo, 2010.

O interesse em células de inseto para a produção de proteínas complexas se deve a sua maior facilidade de cultivo e ao padrão equivalente de glicosilação quando comparado aos sistemas com células de mamíferos. O objetivo deste trabalho foi identificar fatores que limitam ou inibem a produção da glicoproteína do vírus rábico (GPV) expressa na membrana citoplasmática de células de Drosophila melanogaster transfectadas, quando cultivadas em biorreator de bancada agitado e bubble-free, operado em modo descontínuo. Avaliaram-se as influências de oxigênio dissolvido $\left(5<\mathrm{pO}_{2}<80 \%\right)$, da glicose $\left(1<\mathrm{GLC}_{0}<15 \mathrm{~g} / \mathrm{L}\right)$ e da glutamina $\left(0.6<\mathrm{GLN}_{0}<7 \mathrm{~g} / \mathrm{L}\right)$. Essas variáveis afetaram de forma diferenciada o crescimento celular (produção de células e velocidades específicas- $\mu_{\mathrm{X}}$ ), o metabolismo celular (fatores de conversão - $\mathrm{Y}_{\mathrm{X} / \mathrm{GLC}}, \mathrm{Y}_{\mathrm{X} / \mathrm{GLN}}$, $\left.\mathrm{Y}_{\mathrm{LAC} / \mathrm{GLC}}, \mathrm{Y}_{\mathrm{ALA} / \mathrm{GLC}}, \mathrm{Y}_{\mathrm{NH} 4 / \mathrm{GLN}}, \mathrm{Y}_{\mathrm{ALA} / \mathrm{GLN}}\right)$, assim como a expressão da proteína recombinante (concentração, teor celular e produtividade). $\mathrm{O}$ aumento do $\mathrm{pO}_{2}$ reduziu em 9 vezes o crescimento celular mas aumentou o teor celular de GPV em 1,4 vezes. Baixos valores de $\mathrm{GLC}_{0}$ e $\mathrm{GLN}_{0}$, claramente, limitaram o crescimento, de modo que incrementos na concentração desses substratos, até valores intermediários, aumentaram $\mu_{\mathrm{X}, \mathrm{MAX}}$ em 3 vezes e 2,5 vezes, respectivamente, e a produção de células em 11 vezes e 3 vezes, respectivamente. O teor celular de GPV máximo não foi afetado pela GLC, mas aumentou em 100\% para valores de $\mathrm{GLN}_{0}$ igual ou superiores a 3,5 g/L. As concentrações de lactato produzidas foram consideradas baixas (inferiores a $0,8 \mathrm{~g} / \mathrm{L}$ ) para exercer qualquer efeito de inibição sobre o crescimento ou a expressão da proteína. Por sua vez, as concentrações de amônio parecem inibir tanto a produção de GPV $\left(\mathrm{NH}_{4}{ }^{+} \sim 50 \mathrm{mg} / \mathrm{L}\right)$ quanto o crescimento celular $\left(\mathrm{NH}_{4}{ }^{+} \sim 80 \mathrm{mg} / \mathrm{L}\right)$. A condição de cultivo com de $30 \%$ de $\mathrm{pO}_{2}, 10 \mathrm{~g} / \mathrm{L}$ de $\mathrm{GLC}_{0}$ e $3,5 \mathrm{~g} / \mathrm{L}$ de $\mathrm{GLN}_{0}$ resultou nos maiores valores de produtividade $(9,1 \mu \mathrm{g} / \mathrm{L} . \mathrm{h})$ e de concentração de GPV $(1,2 \mathrm{mg} / \mathrm{L})$. O metabolismo de GLC e GLN apresentou grande interdependência, com alterações em GLC $_{0}$ afetando o metabolismo de GLN e vice-versa. Assim, em condições de excesso de GLC $_{0}$, as células apresentaram um metabolismo mais ineficiente com reduções nos fatores $\mathrm{Y}_{\mathrm{X} / \mathrm{GLC}}$ 
(2,3 vezes) e $Y_{X / G L N}$ (4,6 vezes) e maior geração de subprodutos, caracterizada por incrementos nos valores de $\mathrm{Y}_{\mathrm{ALA} / \mathrm{GLC}}(51 \%), \mathrm{Y}_{\mathrm{LAC} / \mathrm{GLC}}(11 \%)$ e $\mathrm{Y}_{\mathrm{NH} 4 / \mathrm{GLN}}(15 \%)$. O metabolismo da GLN apresentou resposta característica de substrato em excesso para toda a faixa de valores ensaiada, com redução de 25 vezes no valor de $\mathrm{Y}_{\mathrm{X} / \mathrm{GLN}} \mathrm{e}$ inesperadamente também uma redução na geração de subprodutos de 7 vezes para $\mathrm{Y}_{\mathrm{NH} 4 / \mathrm{GLN}}$ e 12 vezes para $\mathrm{Y}_{\mathrm{ALA} / \mathrm{GLN}}$. O efeito sobre o metabolismo da GLC foi mais acentuado para valores mais elevados de $\mathrm{GLN}_{0}$, com redução de 3,6 vezes para $\mathrm{Y}_{\mathrm{X} / \mathrm{GLC}} \mathrm{e}$ incrementos de $70 \%$ para $\mathrm{Y}_{\mathrm{ALA} / \mathrm{GLC}}$ e para $\mathrm{Y}_{\mathrm{LAC} / \mathrm{GLC}}$. Os resultados sugerem ainda que a célula utiliza duas vias para metabolizar a glutamina: glutaminólise, em condição de limitação em GLC; ou glutamato sintase - NADH-GOGAT, em condição de excesso em GLC. A célula demonstrou também capacidade de sintetizar GLN, a partir de amônio ou outros aminoácidos, quando atingiu concentrações abaixo de $50 \mathrm{mg} / \mathrm{L}$.

Palavras-chave: Drosophila melanogaster S2. Célula de inseto. Metabolismo. Biorreator. Proteína recombinante. Glicoproteína do vírus rábico. 


\begin{abstract}
AGUIAR, M. A. Kinetic study of Drosophila melanogaster cells transfected to produce the rabies vírus glycoprotein in bioreactor. 2010. 124 p. Master thesis (Biotechnology) - Instituto de Ciências Biomédicas, Universidade de São Paulo, São Paulo, 2010.
\end{abstract}

The interest in using insect cells to produce complex proteins is due to its ease of cultivation and its glycosylation pattern equivalent to that of mammalian cells systems. The objective of this work was to identify the limiting or inhibiting factors for the production of a rabies virus glycoprotein (RVGP), expressed in the cytoplasmatic membrane of a transfected Drosophila melanogaster S2 cells, when cultivated in a bench stirred bubble-free bioreactor, in batch mode. The influence of dissolved oxygen $\left(5<\mathrm{pO}_{2}<80 \%\right)$, of initial glucose concentration $\left(1<\mathrm{GLC}_{0}<15 \mathrm{~g} / \mathrm{L}\right)$ and of initial glutamine concentration $\left(0.6<\mathrm{GLN}_{0}<7 \mathrm{~g} / \mathrm{L}\right)$ was evaluated. These variables affected in a different way cell growth (cell production and specific growth rate - $\mu_{\mathrm{X}}$ ), cell metabolism (yield factors - $\mathrm{Y}_{\mathrm{X} / \mathrm{GLC}}, \mathrm{Y}_{\mathrm{X} / \mathrm{GLN}}, \mathrm{Y}_{\mathrm{LAC} / \mathrm{GLC}}, \mathrm{Y}_{\mathrm{ALA} / \mathrm{GLC}}, \mathrm{Y}_{\mathrm{NH} / \mathrm{GLN}}$ and $\mathrm{Y}_{\mathrm{ALA} / \mathrm{GLN}}$ ), as well as the recombinant protein expression (RVGP concentration, RVGP cell content and RVGP productivity). $\mathrm{pO}_{2}$ increase reduced 9 times cell growth, but increased 1.4 times RVGP cell content. Low initial glucose and glutamine concentrations clearly limited the cell growth, in such a way that raising these substrates concentrations up to intermediate values, increased $\mu_{\mathrm{X}, \mathrm{MAX}} 3$ times and 2.5 times, respectively, and increased cell production 11 times and 3 times, respectively. The maximum RVGP cell content was not affected by $\mathrm{GLC}_{0}$, but improved $100 \%$ when $\mathrm{GLN}_{0}$ was $3.5 \mathrm{~g} / \mathrm{L}$ or higher. The concentrations of produced lactate were considered low (below $0.8 \mathrm{~g} / \mathrm{L}$ ) to cause any inhibition effect on growth or protein expression. On the other hand, ammonium concentrations seem to inhibit RVGP production $\left(\mathrm{NH}_{4}{ }^{+} \sim 50 \mathrm{mg} / \mathrm{L}\right)$, as well as cell growth $\left(\mathrm{NH}_{4}{ }^{+} \sim 80 \mathrm{mg} / \mathrm{L}\right)$. Maximum productivity values $(9.1 \mu \mathrm{g} / \mathrm{L} . \mathrm{h})$ and RVGP concentration $(1.2 \mathrm{mg} / \mathrm{L})$ were attained for $30 \% \mathrm{pO}$, $10 \mathrm{~g} / \mathrm{L}$ of $\mathrm{GLC}_{0}$ and $3.5 \mathrm{~g} / \mathrm{L}$ of $\mathrm{GLN}_{0}$ run. The metabolism of GLC and GLN showed a great interdependence, with $\mathrm{GLC}_{0}$ changes affecting the GLN metabolism, and viceversa. Thus, in glucose excess condition, cell metabolism was less efficient. This implied in reduction of yield factors - $\mathrm{Y}_{\mathrm{X} / \mathrm{GLC}}(2.3$ times $)$ e $\mathrm{Y}_{\mathrm{X} / \mathrm{GLN}}(4.6$ times $)$ - and in 
higher by-products generation, characterized by augmentation in $\mathrm{Y}_{\mathrm{ALA} / \mathrm{GLC}}(51 \%)$, $\mathrm{Y}_{\mathrm{LAC} / \mathrm{GLC}}(11 \%)$ and $\mathrm{Y}_{\mathrm{NH} 4 / \mathrm{GLN}}(15 \%)$. The glutamine metabolism showed a substrate excess response pattern to the whole range of concentration studied, with reduction of $\mathrm{Y}_{\mathrm{X} / \mathrm{GLN}}\left(25\right.$ times) and, unexpectedly, a reduction of by-products liberation - $\mathrm{Y}_{\mathrm{NH} 4 / \mathrm{GLN}}$ (7 times) and $\mathrm{Y}_{\mathrm{ALA} / \mathrm{GLN}}(12$ times). The effect on glucose metabolism was more intense when the glutamine concentration was higher, showing a 3.6 times diminution $\mathrm{Y}_{\mathrm{X} / \mathrm{GLC}}$ and a $70 \%$ augmentation for $\mathrm{Y}_{\mathrm{ALA} / \mathrm{GLC}}$ and $\mathrm{Y}_{\mathrm{LAC} / \mathrm{GLC}}$. The results suggest that cells metabolize glutamine through two different pathways glutaminolysis, under glucose limitation, or glutamate synthase - NADH-GOGAT, under glucose excess. The cell, proved also to be able to synthesize glutamine from ammonium or other amino acids, when it reached concentrations below $50 \mathrm{mg} / \mathrm{L}$.

Keywords: Drosophila melanogaster S2. Insect cells. Metabolism. Bioreactor. Recombinant protein. Rabies virus glycoprotein. 


\section{INTRODUÇÃO}

Os avanços da engenharia genética na década de 70 permitiram uma expansão da indústria biofarmacêutica, pois produtos de alto valor agregado puderam ser produzidos a um custo moderado. Esta expansão teve início com a aprovação, no princípio dos anos 80 , do primeiro processo de produção de insulina humana, utilizando o sistema com E. coli e plasmídeos. Entretanto, a utilização de microrganismos geneticamente modificadas na produção de proteínas é muitas vezes inviável comercialmente, devido à incapacidade destas células de realizarem algumas das modificações pós-traducionais necessárias para o funcionamento biológico correto de proteínas animais mais complexas. De forma que, a tendência ainda é que a maior parte dessas proteínas animais seja produzida, em escala industrial, utilizando-se células de mamíferos e de insetos, apesar dos avanços significativos na busca de soluções para esse gargalo tecnológico dos sistemas microbianos.

A princípio, o interesse nas células de inseto residia na perspectiva de produção de inseticidas virais como uma alternativa ecologicamente importante ao uso de compostos químicos para o controle de pragas. Posteriormente, o atrativo destas células passou a ser o desenvolvimento de vetores de baculovírus para alta expressão de genes heterológos. Rapidamente, células de inseto se tornaram muito interessantes por serem capazes de produzir proteínas complexas com precisão, exigindo condições de cultura mais simples que aquelas necessárias para células de mamíferos. Contudo, a expressão de proteínas em células de inseto apresenta limitações, sendo as principais delas o fato deste ser um sistema de expressão transiente e lítico, o que determina o fim abrupto do cultivo. Isso levou ao surgimento de novas técnicas de expressão de genes. Uma delas é a utilização de promotores virais para o desenvolvimento de células de inseto estavelmente transformadas.

Seguindo essa tendência, em 2003, aprovou-se um projeto temático na Fapesp (Projeto $n^{0}$ 02/09482-3) visando a clonagem dos genes da glicoproteína $\mathrm{G}$ do vírus da raiva em vetores de expressão, para construção de células de dípteros estavelmente transformadas, e a otimização do bioprocesso de produção deste antígeno em culturas celulares em biorreatores, visando a produção de vacinas e kits diagnósticos. Este trabalho envolve grupos de cinco instituições: Instituto Butantan, Universidade Estadual 
de Campinas, Universidade Federal de São Carlos, Instituto de Pesquisas Tecnológicas (IPT) e Universidade de São Paulo.

Com relação à proteína selecionada, apesar de já existirem vacinas eficientes e seguras, para uso humano e veterinário, a raiva ainda é um problema significativo em diversos países da Ásia e da África. Essas regiões são responsáveis pela maior parte das 55 mil mortes anuais reportadas por causa desta doença, sendo que a grande maioria das vítimas são crianças. Apesar da existência de vacinas comprovadamente seguras obtidas através de cultivos celulares, alguns países ainda produzem e utilizam vacinas de tecido nervoso, as quais são menos eficientes, requerem mais visitas ao hospital e, em geral, apresentam efeitos colaterais. Além disso, estes pacientes não recebem a quantidade necessária de imunoglobulina anti-rábica, a qual, devido ao seu alto custo, é inviável economicamente para países onde a raiva canina é endêmica (WORLD HEALTH ORGANIZATION, 2008).

No Brasil, a raiva humana está sob controle. Entretanto, por ser uma zoonose, é difícil erradicar a doença por completo. No início de 2006, o Instituto Butantan começou a produzir, em células Vero, uma vacina de raiva com o vírus inativado visando, inicialmente, suprir a demanda nacional de 3 milhões de doses anuais da vacina, importada da França até então. Num segundo momento, espera-se ampliar o volume de produção, possibilitando a exportação (PIVETA, 2005).

A principal vantagem desta proposta da produção do epítopo da glicoproteína do vírus da raiva para utilização em vacinas é o fato deste sistema produtivo não requerer o mesmo nível de biossegurança que as vacinas produzidas a partir do vírus da raiva, pois não envolve organismos patogênicos. Assim, é possível produzir uma vacina mais barata e acessível.

A linhagem escolhida para a produção da glicoproteína do vírus da raiva foi a S2 - Drosophila melanogaster - um sistema celular bastante utilizado na expressão de proteínas heterólogas, para diversas aplicações. Nos trabalhos disponíveis na literatura até então, o metabolismo e condições de produção e crescimento eram raramente abordados, sendo que a maior parte destas informações era obtida a partir de trabalhos utilizando linhagens de Spodoptera frugiperda, como Sf9 e Sf21, ou de Tricoplusia ni. Os primeiros trabalhos gerados pelo grupo envolvido neste projeto, abordando especificamente o cultivo de células S2 transfectadas para a produção da glicoproteína da raiva, começaram a suprir esta falta de informações. Eles apresentam alguns dos primeiros dados de metabolismo desta linhagem, a qual parece ter comportamentos 
intermediários entre aqueles observados para outras células de inseto e as células de mamífero, além de responder de formas diferentes de acordo com as condições de cultivo utilizadas.

No contexto do projeto Fapesp mencionado anteriormente, o Laboratório de Biotecnologia Industrial do Centro Tecnológico de Processos e Produtos do Instituto de Pesquisas Tecnológicas do Estado de São Paulo tem duas metas: a) estudo dos fatores que limitam e inibem o crescimento de células de Drosophila melanogaster transfectadas, assim como a expressão da glicoproteína do vírus da raiva, empregando um meio de cultura distinto daqueles já estudados pelo grupo e; b) propor um modelo matemático não-estruturado para este sistema de expressão. A primeira destas metas está sendo cumprida por este trabalho de mestrado. 


\section{CONCLUSÕES}

As principais conclusões deste trabalho foram:

1) Níveis de $\mathrm{pO}_{2}$ superiores a $30 \%$ têm efeito inibitório no crescimento celular, indicado pela redução de 9 vezes no valor de $\mu_{\mathrm{X}, \mathrm{MAX}}$ e de 20 vezes no valor de produção de células $(\Delta X)$.

2) Incrementos na disponibilidade de oxigênio causaram ainda alterações no metabolismo, diminuindo a eficiência no consumo de glicose e glutamina e gerando, assim, maiores quantidades de amônio e alanina por molécula de substrato consumido;

3) Nos ensaios com variação de oxigênio, o maior valor de teor celular de GPV foi observado na condição de $\mathrm{pO}_{2}$ de 50\%. Apesar disso, valores máximos de concentração e de produtividade em GPV foram obtidos para $\mathrm{pO}_{2}$ igual ou inferior a $30 \%$;

4) Os resultados obtidos nos ensaios com variação de glicose sugerem limitação por glicose, quando a concentração deste substrato é menor ou igual a $5 \mathrm{~g} / \mathrm{L}$. Por outro lado, a concentração de $15 \mathrm{~g} / \mathrm{L}$ teve efeito negativo no crescimento celular (redução de 20 vezes), mas sem afetar o valor de $\mu_{\mathrm{X}, \mathrm{MAX}}$;

5) A manutenção da viabilidade celular parece estar associada à disponibilidade de glicose no meio de cultura;

6) A variação na concentração inicial de glicose causou alteração no metabolismo celular. Os metabolismos de glicose e glutamina apresentaram ainda grande interdependência, com alterações na concentração inicial de glicose afetando o metabolismo de glutamina e vice-versa;

7) Quando a concentração inicial de glicose aumentou de 1,1 g/L para $10 \mathrm{~g} / \mathrm{L}$, a eficiência nos consumos de glicose e de glutamina aumentaram - 2,1 vez para $Y_{X / G L C}$ e 4,8 vezes para $Y_{X / G L N}$ - diminuindo a produção de amônio e alanina por molécula de substrato - 1,8 vezes para $\mathrm{Y}_{\mathrm{ALA} / \mathrm{GLC}}$ e 3,1 vezes para $\mathrm{Y}_{\mathrm{NH} 4 / \mathrm{GLN}}$; 
8) Para a mesma faixa de valores, o aumento da concentração inicial de glicose sugere uma alteração na via de assimilação da glutamina, com a ativação da via da glutamato sintase - NADH-GOGAT, que se caracteriza pela menor geração de amônio $\left(\mathrm{Y}_{\mathrm{NH} 4 / \mathrm{GLN}} 3,1\right.$ vezes menor);

9) $\mathrm{O}$ teor celular de GPV não apresenta alterações quando se varia a concentração inicial de glicose. Assim, da mesma forma que no crescimento celular, a condição de $10 \mathrm{~g} / \mathrm{L}$ de glicose apresenta os maiores valores de concentração e de produtividade de GPV;

10) Nos ensaios com variação da concentração inicial de glutamina foram obtidos indícios de limitação no crescimento quando a concentração inicial deste aminoácido é menor $1,75 \mathrm{~g} / \mathrm{L}$. Acima desse valor, $\mu_{\mathrm{X}, \mathrm{MAX}}$ é aproximadamente constante, porém a maior concentração celular foi obtida com 3,5 g/L de glutamina.

11) Observaram-se também mudanças no metabolismo celular, que se tornou mais ineficiente (redução de até 25 vezes no valor de $\mathrm{Y}_{\mathrm{X} / \mathrm{GLN}}$ ) para valores crescentes de glutamina, mas inesperadamente apresentou menor formação de subprodutos por molécula de glutamina. Uma hipótese é que as células tenham aumentado a geração de $\mathrm{CO}_{2}$;

12) Altas concentrações de glutamina resultam em um aumento de $100 \%$ no teor celular de GPV. Entretanto, devido às diferenças observadas nos crescimentos celulares, a melhor condição para a concentração e a produtividade de GPV aconteceram com $\mathrm{GLN}_{0}=3,5 \mathrm{~g} / \mathrm{L}$;

13) Todos os resultados obtidos sugerem que a concentração de amônio causa inibição para a produção de GPV $\left(\mathrm{NH}_{4}{ }^{+} \sim 50 \mathrm{mg} / \mathrm{L}\right)$ e para o crescimento celular $\left(\mathrm{NH}_{4}{ }^{+} \sim 80 \mathrm{mg} / \mathrm{L}\right)$;

14) Além da glutamina, os aminoácidos mais consumidos são a cistina, a prolina, metionina, isoleucina, leucina e valina. Entretanto, não se observam indícios de limitação por esgotamento de nenhum destes.

15) A linhagem celular é capaz de produzir glutamina, possivelmente a partir do consumo de outros aminoácidos ou diretamente de amônio, visto que ocorre consumo simultâneo deste subproduto;

16) A condição ótima para produção da glicoproteína do vírus da raiva foi obtida para $\mathrm{pO}_{2}=30 \%, \mathrm{GLC}=10 \mathrm{~g} / \mathrm{L}$ e $\mathrm{GLN}=3,5 \mathrm{~g} / \mathrm{L}$. Nessas 
condições, os valores de produtividade observados foram de 9,1 $\mu \mathrm{g} / \mathrm{L} . \mathrm{h}$ e os de concentração de GPV de 1,2 mg/L. 


\section{REFERÊNCIAS ${ }^{1}$}

ALOI, L. E.; CHERRY, R. S. Cellular Response to Agitation Characterized by Energy Dissipation at The Impeller Tip. Chemical Engineering Science, v. 51, p. 1523-1529, 1996.

ALTAMIRANO, C.; GODIA, F.; CAIRÓ, J.J. Metabolismo de células de mamíferos cultivadas in vitro. In.: MORAES, A.M.; AUGUSTO, E.F.P.; CASTILHO, L.R.; Tecnologia do cultivo de células animais: de biofármacos a terapia gênica. São Paulo: Ed. Roca, 2008. p. 105-119.

ALTMANN, F; STAUDACHER, E.; WILSON, I. B. H.; MARZ, L. Insect cells as hosts for the expression of recombinant glycoproteins. Glycoconjugate Journal, v. 16, p. 109-123, 1999.

ALVES, P. M. M.; CARRONDO, M. J. T.; CRUZ, P. E. Introdução `tecnologia de cultivo de células animais. In.: MORAES, A.M.; AUGUSTO, E.F.P.; CASTILHO, L.R.; Tecnologia do cultivo de células animais: de biofármacos a terapia gênica. São Paulo: Ed. Roca, 2008. p. 2-14.

AMABLE, P.; BUTLER, M. Cell metabolism and its control in culture. In.: MORAES, A.M.; AUGUSTO, E.F.P.; CASTILHO, L.R.; BUTLER, M.; Animal cell technology. from biopharmaceuticals to gene therapy. London: Taylor \& Francis, 2008. p. 75-110.

ASHBURNER, M. Drosophila, a laboratory handbook. New York: Cold Spring Harbour Press, 1989.

ASTRAY, R. M. Expressão da glicoproteína recombinante do vírus rábico em sistemas Drosophila melanogaster (S2) e Semliki Forest Virus (SFV). 142 f. Tese (Doutorado em Biotecnologia) - Instituto de Ciências Biomédicas, Universidade de São Paulo, São Paulo, 2009.

ASTRAY, R. M.; AUGUSTO, E. F. P; YOKOMIZO, A. Y.; PEREIRA, C. A. Analytical approach for the extraction of recombinant membrane viral glycoprotein from stably transfected Drosophila melanogaster cells. Biotechnology Journal, v. 3, p. 98-103, 2008.

AUGUSTO, E. F. P.; OLIVEIRA, M. S. Processos com células animais. In: LIMA, U. A.; AQUARONE, E.; BORZANI, W.; SCHMIDELL, W. (Ed.). Biotecnologia Industrial São Paulo: Edgar Blücher, 2001. p. 547-582, v.3.

\footnotetext{
${ }^{1}$ De acordo com: ASSOCIAÇÃO BRASILEIRA DE NORMAS TÉCNICAS. NBR 6023:

Informação e documentação: referências: elaboração. Rio de Janeiro, 2002.
} 
BACHMANN, A. S.; CORPUZ, G.; HARELD, W. P.; WANG, G.; COLLER, B. A. A simple method for the rapid purification of copia virus-like particles from Drosophila Schneider 2 cells. Journal of Virological Methods, v.115, p.159-165, 2004.

BAILEY, J. E.; OLLIS, D. F. Biochemical engineering fundamentals, New York: McGraw-Hill International editions., 1986.

BANKS, D. J.; HUA, G.; ADANG, M. J. Cloning of a Heliothis virescens $110 \mathrm{kDa}$ aminopeptidase $\mathrm{N}$ and expression in Drosophila S2 cells. Insect Biochemistry and Molecular Biology, v. 33, p. 499-508, 2003.

BATISTA, F. R. X.; PEREIRA, C. A.; MENDONÇA, R. Z.; MORAES, A. M. Formulation of a protein-free medium based on IPL-41 for the sustained growth of Drosophila melanogaster S2 cells. Cytotechnology. v. 57, p. 11-22, 2008.

BATISTA, F. R. X.; MORAES, A. M.; BÜNTEMEYER, H.; NOLL, T. Influence of culture conditions on recombinant Drosophila melanogaster S2 cells producing rabies virus glycoprotein cultivated in serum-free medium. Biologicals, v. 37, p. 108-118, 2009.

BENSLIMANE, C.; ELIAS, C. B.; HAWARI, J.; KAMEN, A. Insights into the central metabolism of Spodoptera frugiperda (Sf-9) and Trichoplusia ni BTI-Tn-5B1-4 (Tn-5) insect cells by radiolabelling studies. Biotechnology Progress, v. 21, p. 78-86, 2005.

BERDARD, C.; TOM, R.; KAMEN, A. Growth, nutrient consumption and end-product accumulation in $\mathrm{Sf} 9$ and BTI-EAA insect cell cultures: Insights into growth limitation and metabolism. Biotechnology Progress, v.9, p.615-624, 1993.

BERNAL, V.; CARINHAS, N.; YOKOMIZO, A. Y.; CARRONDO, M. J. T.; ALVES, P. M. Cell densitiy effect in the baculovirus-insect cells system: A quantitative analysis of energetic metabolism. Biotechnology and Bioengineering, v. 104, p. 162-180, 2009.

BIBILA, T. A.; FLICKINGER, M. C. A model of interorganelle monoclonal antibody transport and secretion in mouse hybridoma cells. Biotechnology and Bioengineering, v. 38, p. 767-780, 1991.

BORASH, D. J.; PIERCE, V. A.; GIBBS, A. G.; MUELLER, L. D. Evolution of ammonia and urea tolerance in Drosophila melanogaster: resistance and crosstolerance. Journal of Insect Physiology, v. 46, p. 763-769, 2000.

BOVO, R.; GAlESI, A. L. L.; JORGE, S. A. C.; PICCOLI, R. A. M.; MORAES, A. M.; PEREIRA, C. A.; AUGUSTO, E. F. P. Kinetic response of a Drosophila melanogaster cell line to different medium formulations and culture conditions. Cytotechnology, v. 57, p. 23-35, 2008.

BUTLER, M. Animal Cell Culture and Technology. London: BIOS, 2004.

BUTLER, M. Modificações pós-tradução em proteínas recombinantes. In.: MORAES, A. M.; AUGUSTO, E. F. P.; CASTILHO, L. R.; Tecnologia do cultivo de células animais: de biofármacos a terapia gênica. São Paulo: Ed. Roca, 2008. p. 122-137. 
CARSWELL, K. S.; PAPOUTSAKIS, E. T. Culture of Human T-Cells in Stirred Bioreactors for Cellular Immunotherapy Applications: Shear, Proliferation, and the IL-2 Receptor. Biotechnology and Bioengineering, v. 68, p. 328-338, 2000.

CHA, H. J.; SHIN, H. S.; LIM, H. J.; CHO, H. S.; DALAL, N. N.; PHAM, M. Q.; BENTLEY, W. E. Comparative production of human interleukin-2 fused with green fluorescent protein in several recombinant expression systems. Biochemical Engineering Journal, v. 24, p. 225-233, 2005.

CHERBAS, M. L.; CHERBAS, P. Transformation techniques for Drosophila cell lines. Methods in Cell Biology, v. 44, p. 161-179, 1994.

CHICO, E.; RODRÍGUEZ, G.; FIGUEREDO, A. Biorreatores para células animais. In.: MORAES, A. M.; AUGUSTO, E. F. P.; CASTILHO, L. R.; Tecnologia do cultivo de células animais: de biofármacos a terapia gênica. São Paulo: Ed. Roca, 2008. p. 216254.

CHISTI, Y. Animal Cell Damage in Sparged Bioreactors. Trends in Biotechnology, v. 18, p. 420-432, 2000.

COX, J. H.; DIETZSCHOLD, B.; SCHNEIDER, L. G. Rabies virus glycoprotein II. Biological and serological characterization. Infection and Immunity, v.16, p. 754-759, 1977.

DEML, L; WOLF, H.; WAGNER, R. High level expression of hepatitis B virus surface antigen in stably transfected Drosophila Schneider-2 cells. Journal of Virological Methods, v.79, p.191-203, 1999a.

DEML L.; SCHIRMBECK, R.; REIMANN, J.; WOLF, H.; WAGNER, R. Purification and characterization of hepatitis B virus surface antigen particles produced in Drosophila Schneider-2 cells. Journal of Virological Methods, v.79, p.205-217, 1999b.

DEPARIS, V.; DURRIEU, C.; SCHWEIZER, M.; MARC, I.; GOERGEN, J. L.; CHEVALOT, I.; MARC, A. Promoting effect of rapeseed proteins and peptides on Sf9 insect cell growth. Cytotechnology, v.42, p.75-85, 2003.

DESHPANDE, R. R.; HEINZLE, E. Online monitoring of oxygen in spinner flasks. Biotechnology Letters, v. 31, p. 665-669, 2009.

DONALDSON, M.; WOOD, H. A.; KULAKOSKY, P. C. Glycosalytion of a recombinant protein in the Tn5B1-4 insect cell line: Influence of ammonia, time of harvest, temperature, and dissolved oxygen. Biotechnology and Bioengineering, v. 63, p. 255-262, 1999.

DOVERSKOG, M.; JACOBSON, U.; CHAPMAN, B. E.; KUCHEL, P. W.; HÄGGSTRÖM, L. Determination of NADH-dependent glutamate synthase (GOGAT) in Spodoptera frugiperda (Sf9) insect cells by a selective ${ }^{1} \mathrm{H} /{ }^{15} \mathrm{~N}$ NMR in vitro assay. Journal of Biotechnology, v. 79, p. 87-97, 1997. 
DREWS, M.; PAALME, T.; VILU, R. The growth and nutrient utilization of insect cell line Spodoptera frugiperda $\mathrm{Sf} 9$ in batch and continuous culture. Journal of Biotechnology, v. 40, p. 187-198, 1995.

DREWS, M.; DOVERSKOG, M.; ÖHMAN, L.; CHAPMAN, B. E.; JACOBSSON, U.; KUCHEL, P. W.; HÄGGSTRÖM, L. Pathways of glutamine metabolism in Spodoptera frugiperda ( $\mathrm{Sf} 9$ ) insect cells: evidence for the presence of the nitrogen assimilation system, and a metabolic switch by ${ }^{1} \mathrm{H} /{ }^{15} \mathrm{~N}$ NMR. Journal of Biotechnology, v. 78, p. 23-37, 2000.

ECHALIER, G. Drosophila cells in culture. New York: Academic Press, 1997. p. 439511.

FERRANCE, J. P.; GOEL, A.; ATAAI, M. N. Utilization of glucose and aminoacids in insect cell culture: Quantifying the metabolic flows within the primary pathways and medium development. Biotechnology and Bioengineering, v.42, p.697-707, 1993.

FERRER-MIRALES, N.; DOMINGO-ESPÍN, J.; CORCHERO, J. L.; VÁZQUEZ, E.; VILLAVERDE, A. Microbial factories for recombinant pharmaceuticals. Microbial Cell Factories, v.8, p. 1-8, 2009.

FRESHNEY, R. I. Culture of animal cells: a manual of basic technique, 3. Ed. New York: Wiley-Liss, 1994.

GALESI, A. L. L. Cultivo de células de Drosophila melanogaster em diferentes formulações de meios de cultura livres de soro visando a produção da glicoproteína do vírus da raiva. 177 f. Tese (Doutorado em Engenharia Química). Faculdade de Engenharia Química, Universidade Estadual de Campinas, Campinas, 2007

GALESI, A. L. L.; PEREIRA, C. A.; MORAES, A. M. Culture of transgenic Drosophila melanogaster Schneider 2 cells in serum-free media based on TC100 basal medium. Biotechnology Journal, v. 2, p. 1399-1407, 2007.

GAleSi, A. L. L.; AGUiAR, M. A.; ASTRAY, R. M.; AUGUSTO, E. F. P.; MORAES, A. M. Growth of recombinant Drosophila melanogaster Schneider 2 cells producing rabies virus glycoprotein in bioreactor employing serum-free medium. Cytotechnology. v. 57, p. 73-81, 2008.

GARDNER, A. R.; GAINER J. L.; KIRWAN, D. J. Effects of Stirring and Sparging on Cultured Hybridoma Cells. Biotechnology and Bioengineering, v. 35, p. 940-947, 1990.

GARDSVOLL, H.; WERNER, F.; SONDERGAARD, L.; DANO, K.; PLOUG, M. Characterization of low-glycosylated forms of soluble human urokinase receptor expressed in Drosophila Schneider 2 cells after deletion of glycosylation-sites. Protein Expression and Purification. v. 34, p. 284-295, 2004. 
GIBSON, K. R.; VANEK, P. G.; KALOSS, W. D.; COLLIER, B.; CONNAUGHTON, J. F.; MONICA ANGELICHIO, M.; LIVI, G. P.; FLEMING, P. J. Expression of Dopamine $\beta$-hydroxylase in Drosophila Schneider 2 cells. Evidence for a mechanism of membrane binding other than uncleaved signal peptide. The Journal of Biological Chemistry, v. 268, p. 9490-9495, 1993.

GORJÃO, R. Contagem de células. In: CURI, R.; PERES, C. M.; Como cultivar células. Rio de Janeiro: Guanabara Koogan, 2005. p. 22-24.

GOTOH, T.; MIYAZAKI, Y.; CHIBA, K.; KIKUCHI, K. Significant increase in recombinant protein production of a virus-infected Sf9 insect cell culture of low MOI under low dissolved oxygen conditions. Journal of Bioscience and Bioengineering, v.94, p. 426-433, 2002.

GUTTERIDGE, J. M. C.; HALLIWELL, B. The measurement and mechanism of lipid peroxidation in biological systems. Trends in Biochemical Sciences, v. 15, p. 129-135, 1990.

HEWLETT, G. Strategies for optimizing serum-free media. Cytotechnology, v. 5, p. 3$14,1991$.

IKONOMOU, L.; SCHNEIDER, Y. J.; AGATHOS, S. N.. Insect cell culture for industrial production of recombinant proteins. Applied Microbiology and Biotechnology, v.62, p.1-20, 2003.

IKONOMOU, L.; BASTIN, G.; SCHNEIDER, Y. J.; AGATHOS, S. N. Effect of partial medium replacement on cell growth and protein production for High-Five ${ }^{\mathrm{TM}}$ insect cell culture. Cytotechnology, v. 44, p. 67-76, 2004.

JARVIS, D. L., FLEMING, J. G. W., KOVACS, G. R.. Use of early baculovirus promoters for continuos expression and efficient processing of foreign gene products in stably transformed lepidopteran cells. Nature Biotechnology, v.8, p.950-955, 1990.

JEON, H. K.; CHANG, K. H.; KIM, K. I.; CHUNG, I. K. Functional expression of recombinant tumstatin in stably transformed Drosophila melanogaster S2 cells. Biotechnology Letters, v.25, p.185-189, 2003.

JEONG, Y. H.; WANG, S. S. Role of glutamine in hybridoma cell culture: Effects of cell growth, antibody production, and cell metabolism. Enzyme and Microbial Technology, v. 17, p. 47-55, 1995.

JOHANSSON, D. X.; DRAKENBERG. K.; HOPMANN, K. H.; SCHMIDT, A.; YARI, F.; HINKULA, J.; PERSSON, M. A. A. Eficient expression of recombinant human monoclonal antibodies in Drosophila S2 cells. Journal of Immunological Methods. v. 318, p. 37-46, 2007.

JORGE, S. A. C.; SANTOS, A. S.; SPINA, A.; PEREIRA, C. A. Expression of the hepatitis B vírus surface antigen in Drosophila S2 cells. Cytotechnology, v. 57, p. 51$59,2008$. 
JURAT-FUENTES, J. L.; ADANG, M. J. The Heliothis virescens Cadherin protein expressed in Drosophila S2 cells functions as a receptor for Bacillus thuringiensis Cryla but not Cry1Fa toxins. Biochemistry, v. 45, p. 9688-9695, 2006.

KIOUKIA, N.; NIENOW, A. W.; AL-RUBEAI, M.; EMERY, A. N. Influence of agitation and sparging on the growth rate and infection of insect cells in bioreactors and a comparison with hybridoma culture. Biotechnology Progress, v. 12, p. 779-785, 1996.

KIRKPATRICK, R. B.; GANGULY, S.; ANGELICHIO, M.; GRIEGO, S.; SHATZMAN, A.; SILVERMAN, C.; ROSENBERG, M. Heavy chain dimmers as well as complete antibodies are efficiently formed and secreted from Drosophila via a BiPmediated pathway. Journal of Biological Chemistry, v.270, p. 19800-19805, 1995.

KONZ, J. O.; KING, J.; COONEY, C. L. Effects of oxygen on recombinant protein expression. Biotechnology Progress, v. 14, p. 393-409, 1998.

KUNAS, K. T.; PAPOUTSAKIS, E. T. Damage mechanisms of suspended animal cells in agitated bioreactors with and without bubble entrainment. Biotechnology and Bioengineering, v. 36, p. 476-483, 1990.

KUNKEL, J. P.; JAN, D. C. H.; BUTLER, M.; JAMIESON, J. C. Comparisons of the glycosylation of a monoclonal antibody produced under nominally identical cell culture conditions in two different bioreactors. Biotechnology Progress, v. 16, p. 462-470, 2000 .

LEE, J. M.; PARK, J. H.; PARK, J. O.; CHANG, K. H; CHUNG, I. S. Expression of recombinant erythropoietin in stably transformed Drosophila melanogaster S2 cells. In Vitro Cellular and Developmental Biology (Animal), v.36, p.348-350, 2000.

LEMOS, M. A. N.; SANTOS, A. S.; ASTRAY, R. M.; PEREIRA, C. A.; JORGE, S.A.C. Rabies vírus glycoprotein expression in Drosophila S2 cells. I: Design of expression/selection vectors, subpopulations selection and influence of sodium butyrate and culture medium on protein expression. Journal of Biotechnology, v. 143, p. 103$110,2009$.

LI, H. C.; HUANG, C. C.; CHEN, S. F.; CHOU, M. Y. Assembly of homotrimeric type XXI minicollagen by coexpression of prolyl 4-hydroxylase in stably transfected Drosophila melanogaster S2 cells. Biochemical and Biophysical Research Communications, v. 336, p. 375-385, 2005.

LIM, H. J.; CHA, H. J. Observation and modeling of induction effect on human transferring production from stably transfected Drosophila S2 cell culture. Enzyme and Microbial Technology, v. 39, p. 208-214, 2006.

MARTINELLE, K.; DOVERSKOG, M.; JACOBSSON, U.; CHAPMAN, B. E.; KUCHEL, P. W.; HÄGGSTRÖM, L. Elevated glutamate dehydrogenase flux in glucose-deprived hybridoma and myeloma cells: Evidence from 1H/15N NMR. Biotechnology and Bioengineering, v. 60, p. 508-517, 1998. 
MARZZOCO, A.; TORRES, B. B. Bioquímica básica. $3^{\mathrm{a}}$ Ed. Rio de Janeiro: Guanabara Kougan, 2007.

MAZOCCO, C.; FUKASAWA, K. M.; AUGUSTE, P.; PUIROUX, J. Characterization of a functionally expressed dipeptidyl aminopeptidase III from Drosophila melanogaster. European Journal of Biochemistry, v. 270, p. 3074-3082, 2003.

McCARROLL, L.; KING, L. A. stable insect cell cultures for recombinant protein production. Current Opinion in Biotechnology, v. 8, p. 590-594, 1997.

McQUEEN, A.; BAILEY, J. E. Influence of serum level, cell line, flow type anda viscosity on flow-induced lysis of suspended mammalian cells. Biotechnology Letters, v.11, p.531-536, 1989.

MEIER, S. J.; HATTON, T. A.; WANG, D. I. C. Cell death from bursting bubbles: role of cell attachment to rising bubbles in sparged reactors. Biotechnology and Bioengineering, v. 62, p. 468-478, 1999.

MENDONÇA, R. Z.; GRECO, K. N.; SOUSA, A. P. B.; MORAES, R. H. P.; ASTRAY, R. M.; PEREIRA, C. A. Enhancing effect of a protein from Lonomia oblique hemolymph on recombinant protein production. Cytotechnology, v. 57, p. 83-91, 2008 .

MILLAR, N. S.; BAYLIS, H. A.; REAPER, C.; BUNTING, R.; MASON, W. T.; SATTELLE, D. B. Functional expression of a cloned Drosophila muscarinic acetylcholine receptor in a stable Drosophila cell line. The Journal of Experimental Biology, v. 198, p. 1843-1850, 1995.

MITSUHASHI, J. Insect cell line: aminoacid utilization and requirements. In: KURSTAK, E.; MARAMOROSCH, K. (Ed.). Invertebrate tissue culture. New York: Academic Press, 1976. p. 257-262.

MITSUHASHI, J. Invertebrate Cell System Applications. Boca Raton: CRC Press, 1989.

MORAES, A. M.; MENDONÇA, R. Z.; SUAZO, C. A. T. Meios de cultura para células animais. In.: MORAES, A. M.; AUGUSTO, E. F. P.; CASTILHO, L. R.; Tecnologia do cultivo de células animais. de biofármacos a terapia gênica. São Paulo: Ed. Roca, 2008. p. 105-119.

MORAES, I. O. Produção de microrganismos. In.: LIMA, U.A.; AQUARONE, E.; BORZANI, W.; SCHMIDELL, W. (Ed.). Biotecnologia Industrial, São Paulo: Editora Edgard Blücher, 2001, p. 199-218. v. 3.

NEERMANN, J.; WAGNER, R. Comparative analysis of glucose and glutamine metabolism in transformed mammalian cell lines, insect and primary liver cells. Journal of Cellular Physiology, v. 166, p. 152-169, 1996.

NICKLA, H.; FUJIWARA, D.; FRIED, R. Influence of oxygen concentration on development of Drosophila melanogaster. Experientia, v. 38, p. 114-115, 1982. 
ÖHMAN, L.; LJUNGGREN, J.; HÄGGSTRÖM, L. Induction of a metabolic switch in insect cells by substrate-limited fed-batch. Applied Microbiology and Biotechnology, v. 43, p. 1006-1013, 1995.

ÖHMAN, L.; ALARCON, M.; LJUNGGREN, J.; RAMQVIST, A. K.; HÄGGSTRÖM. Glutamine is not an essencial amino acid for Sf-9 insect cells. Biotechnology Letters, v. 18, p. 765-770, 1996.

OZTURK, S. S.; PALSSOM, B. O. Effects of dissolved oxygen on hybridoma cell growth, metabolism and antibody production kinetics on continuous culture. Biotechnology Progress, v. 6, p. 437-446, 1990.

PALOMARES, L. A.; GONZÁLEZ, M.; RAMIREZ, O. T. Evidence of Pluronic F68 direct interaction with insect cells: impact on shear protection, recombinant protein, and baculovirus production. Enzyme and Microbial Technology, v. 26, p. 324-331, 2000.

PAMBOUKIAN, M. M. Estudo da atividade respiratória de linhagens selvagens e transfectadas de células de insetos através de cultivos em biorreatores. $181 \mathrm{f}$. Dissertação (Mestrado em Engenharia Química). Escola Politécnica, Universidade de São Paulo, São Paulo, 2007.

PAMBOUKIAN, M. M.; JORGE, S. A. C.; SANTOS, M. G.; YOKOMIZO, A. Y.; PEREIRA, C. A.; TONSO, A. Insect cells respiratory activity in bioreactor. Cytotechnology, v. 57, p. 37-44, 2008.

PAPOUTSAKIS, E. T. Fluid-Mechanical Damage of Animal Cells in Bioreactors. Trends in Biotechnology, v. 9, p. 427-437, 1991.

PÉREZ, O; PAOLAZZI, C. C. Production methods for rabies vaccine. Journal of Industrial Microbiology and Biotechnology, v. 18, p. 340-347, 1997.

PERRET, B. G.; WAGNER, R.; LECAT, S.; BRILLET, K.; RABUT, G.; BUCHER, B.; PATTUS, F. Expression of EGFP-amino-tagged human mu opioid receptor in Drosophila Schneider s cells: a potential expression system for large-scale production of G-protein coupled receptors. Protein Expression and Purification. V. 31, p. 123132, 2003.

PERRIN, P.; JACOB, Y.; TORDO, N. DNA-Based Immunization against Lyssaviruses. Intervirology, v. 43, p. 302-311, 2000.

PIVETA, M. Nova vacina contra a raiva. Pesquisa Fapesp, São Paulo, v. 115, 2005 Disponível em $<$ http://revistapesquisa.fapesp.br/?art=2830\&bd=1\&pg=1\&lg $>$, Acesso em: maio/2009.

RAMIREZ, O. Principios e aplicações del sistema de expressión de células de insectobaculovírus. In: Production of Biopharmaceuticals in Animal Cell Culture, CBAA Course, Rio de Janeiro, R.J., Brasil, Julho/2004. 
RHIEL, M.; MITCHELL-LOEGEAN, C. M.; MURHAMMER, D. W. Comparison of Trichoplusia ni BTI-Tn-5B1-4 (High Five) and Spodoptera frugiperda Sf9 insect cell line metabolism in suspension cultures. Biotechnology and Bioengineering, v.55, p. 909-920, 1997.

SAARINEN, M.A.; MURHAMMER, D.W. The response of virally infected insect cells to dissolved oxygen concentration: recombinant protein production and oxidative damage. Biotechnology and Bioengineering, v. 81, p. 106-114, 2003.

SESHACHALAM, R. V.; SUBRAMANYAM, V. V.; KRISHNAMOORTHY, R. V. New pathway of utilization of ammonia nitrogen for the synthesis of amino acids through NADH dependent transminases in Bombyx mori. Physiological Entomology, v. 17, p. 281-287, 1992.

SCHNEIDER, I. Cell lines derived from late embryonic stages of Drosophila melanogaster. Journal of Embryology and Experimental Morphology, v. 27, p. 353$365,1972$.

SCOTT, T. R. I.; BLANCHARD, J. H.; FERGUNSON, C. H. R. Effects of oxygen on recombinant protein production by suspension cultures of Spodoptera frugiperda (Sf9) insect cells. Enzyme Microbiology and Technology, v.14, p.798-804, 1992.

SERRATO, J. A.; PALOMARES, L. A.; MENESES-ACOSTA, A.; RAMIREZ, O. T. Heterogeneous conditions in dissolved oxygen affect $\mathrm{N}$-glycosylation but not productivity of a monoclonal antibody in hybridoma cultures. Biotechnology and Bioengineering, v. 88, p. 176-188, 2004.

SONDERGAARD, L. Drosophila cells can grown to high cell densities in a biorreator. Biotechnology Techniques, v.10, p.161-166, 1996.

STRAVOULAKIS, D. A.; KALOGERAKIS, N.; BEHIE, L. A. Growth characteristics of Bombyx mori. Insect cell line in stationary and suspension culture. Canadian journal of chemical engineering, v.69, p.457-464, 1991.

STREET, J. C.; DELORT, A. M.; BRADDOCK, P. S. H.; BRINDLE, K. M. A ${ }^{1} \mathrm{H} /{ }^{15} \mathrm{~N}$ n.m.r. study of nitrogen metabvolism in cultured mammalian cells. Biochemical Journal, v.291, p. 485-492, 1993.

SUGIURA, T.; AMANN, E. Properties of two insect cell lines useful for the baculovirus expression system in serum-free culture. Biotechnology and Bioengineering, v. 51, p. 494-499, 1996.

SWIECH, K.; ROSSI, N; SILVA, B. G.; JORGE, S. A. C.; ASTRAY, R. M.; SUAZO, C. A. T. Bioreactor culture of recombinant Drosophila melanogaster S2 cells: characterization of metabolic features related to cell growth and production of the rabies virus glycoprotein. Cytotechnology, v. 57, p. 61-66, 2008a.

SWIECH, K.; ROSSI, N.; ASTRAY, R. M.; SUAZO, C. A. T. Enhanced production of recombinant rabies virus glycoprotein (rRVGP) by Drosophila melanogaster S2 cells through control of culture conditions. Cytotechnology, v. 57, p. 67-72, $2008 \mathrm{~b}$. 
SWIECH, K.; SILVA, C. S.; ARANTES, M. K.; SANTOS, A. S.; ASTRAY, R. M.; PEREIRA, C. A.; SUAZO, C. A. T. Characterization of growth and metabolism of Drosophila melanogaster cells transfected with the rabies-virus glycoprotein gene. Biotechnology and Applied Biochemistry, v. 49, p. 41-49, 2008c.

TATICEK, R. A.; CHOI, C.; PHAN, S. E.; PAlOMARES, L. A.; SHUlER, M. L. Comparison of growth and recombinant protein expression in two different cell lines in attached and suspension culture. Biotechnology Progress, v.17, p. 676-684, 2001.

TOMIYA, N.; BETENBAUGH, M. J.; LEE, Y. C. Humanization of lepidopteran insect-cell produced glycoproteins. Accounts of Chemical Research, v. 36, p. 613-620, 2003.

TOMIYA, N.; NARANG, S.; LEE, Y. C.; BETENBAUGH, M. J. Comparing N-glycan processing in mammalian cell lines to native and engineered lepidopteran insect cell lines. Glycoconjugate Journal, v. 21, p. 343-360, 2004.

TORFS, H.; SHARIATMADARI, R.; GUERRERO, F.; PARMENTIER, M.; POELS, J.; POYER, W. V.; SWINNEN, E.; DE LOOF, A.; AKERMAN, K.; BROECK, J. V. Characterization of a receptor for insect Tachykinin-Like peptide agonists by functional expression in a stable Drosophila Schneider 2 cell line. Journal of Neurochemistry. v. 74, p. 2182-2189, 2000.

TRAMPER, J.; VLAK, J. M.; GOOIJER, C. D. Scale-up Aspects os Sparged Insect Cells Bioreactors. Cytotechnology, v.20, p.221, 1996.

TURRENS, J. Superoxide production by the mitochondrial respiratory chain. Bioscience Reports, v. 17, p. 3-8, 1997.

VALLE, M. A.; KESTER, M. B.; BURNS, A. L.; MARX, S. J.; SPIEGEL, A. M.; SHILOACH, J. Production and purification of human menin from Drosophila melanogaster S2 cells using stirred tank reactor. Cytotechnology, v.35, p. 127-135, 2001.

VAN DER POL, L.; TRAMPER, J. Shear sensitivity of animal cells from a culturemedium perspective. Trends in Biotechnology, v. 16, p. 323-328, 1998.

VERMA, R.; BOLETI, E.; GEORGE, A. J. T. Antibody engineering: Comparison of bacterial, yeast, insect and mammalian expression systems. Journal of Immunological Methods, v. 216, p. 165-181, 1998.

WORLD HEALTH ORGANIZATION. Human and Animal Rabies, Disponível em

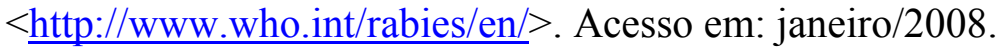

YIN, J.; LI, G.; REN, X.; HERRLER, G. Select what you need: A comparative evaluation of the advantages and limitations of frequently used expression systems for foreign genes. Journal of Biotechnology, v. 127, p. 335-347, 2007. 
YOKOMIZO, A. Y.; JORGE, S. A. C.; ASTRAY, R. M.; FERNANDES, I.; RIBEIRO, O. G.; HORTON, D. S. P.; TONSO, A.; TORDO, N.; PEREIRA, C. A. Rabies virus glycoprotein expression in Drosophila S2 cells. I. Functional recombinant protein in stable co-transfected cell line. Biotechnology Journal, v. 2, p. 102-109, 2007. 